\title{
Corporate Culture And Balanced Scorecard Use: Evidence From Iraqi Manufacturing Industries
}

\author{
Khalis Al-Naser, Rapiah Mohamed
}

\begin{abstract}
The aim of this research is to articulate and test the relationships between corporate culture and the use of Balanced Scorecard (BSC). The framework of this research is centered on the contingency theory. Corporate culture involves four traits, which are adaptability, involvement, consistency, and mission, while BSC consists of four viewpoints such as financial, customer, internal business processes and learning and growth. The Smart PLS was used in analyzing the data collected from Iraqi manufacturing firms through a questionnaire. The results of a survey reveal that is a positive relationship exists between corporate culture and the usage of BSC. The outcomes add to the understanding in strategic management accounting as there is limited evidence on the link between corporate culture and BSC, particularly in Arab countries. This study shed a light on the importance of corporate culture and its effect on BSC.
\end{abstract}

Index Terms: Balanced Scorecard, Corporate Culture, Iraq

\section{INTRODUCTION}

Ever Since the initiation of the balanced scorecard (BSC) by Kaplan [1], this tool has been received enormous interest from scholars and experts. This is due to the claim by [1] that BSC has a power to enhance organizational performance through a causal relationship of four viewpoints (financial, customers, internal business and innovation \& learning) in BSC. The BSC helps the organisation to implement its business strategy, where the strategic objectives, criteria, and actions plans are formulated in each perspective [2]. The balanced scorecard (BSC) has become one of the key agenda for the managers of all organizations [3]. Many organizations nowadays attempt to enhance their performance by using strategic performance measurement system such as BSC. The top management must have the ability to recognize firm activities and the relevant strategies to assist firms in maintaining its long term performance [4]. For instance, companies should give adequate consideration to sustaining an efficient performance measurement system (PMS), as this is vital for their existence [5].

Traditional PMS that solely rely only on financial measures had been argued to unable to support strategic decision making due to several factors such as unable to provide accurate information for decision making; does not take into account the necessities of today's organization and policy; and, promotes short-term thinking and suboptimization [2]. However, organization nowadays are operated in different situations where the business

Revised Manuscript Received on April 19, 2019.

Khalis Al-Naser, Department of Accounting, University of Mosul / Administration and Economic College / Ministry of Higher Education and Scientific Research, Iraq.

Rapiah Mohamed, Tunku Puteri Intan Safinaz School of Accountancy, College of Business, Universiti Utara Malaysia, Kedah, Malaysia. environment is fast changing because of competition, technology, and customer. Regarding this, the organization needs to manage unmeasurable activities such as innovation and human capital. Under the new kind of economic environment, organizations had to pay attention to the factors that nurture innovation, for example, knowledge, new technologies and software products and corporate culture [2]. Consequently, traditional PMS has become less relevant in this situation.

Kaplan [6] claimed that BSC is a strategic control mechanism. The BSC contains four viewpoints- financial, customers, internal business process and learning and growth. The idea of the BSC enables organizations to achieve a cohesive and supported balanced emphasis among these four viewpoints, which jointly reinforce the accomplishment of the company's vision [7]. These four perspectives are a blend of lagging measures (financial) and leading measures (customer, internal business and learning and growth). This will aid the organization to achieve shortterm objectives without sacrifice long-term goals. Through the balancing between financial and non-fiscal measures, an organization can evaluate its accomplishment in developing vital resources, essential in terms of its plan to maintain a competitive advantage. By adopting BSC approach, the organization may necessitate some considerable shifts in culture, because BSC necessitates insight, dedication, and assistance from the very pinnacle of the business and all levels of employees [7]. There is evidence that BSC is an important source to improve organizational performance [8]-[10].

This study was motivated by the recent and extensive use of BSC. The current study examined the practice of BSC using contingency theory, which opines that the layout and utilization of performance measurement based upon organizational and environmental settings [11].

It is conjectured that an improved match amongst BSC and relative variables such as corporate culture, precedes enhanced corporate performance [12]-[13], whilst inadequate fit signifies reduced performance.

Despite the importance of BSC, the important part of corporate culture in activating the role of $\mathrm{BSC}$, and considered as an immersed topic for achieving organizational excellences [14]-[16]. However, there is an apparent shortage of research centering on the connection between corporate culture and the usage of BSC. For 
example, Rababah [16] mentioned that there have been very few empirical researches on the relationship between organizational culture and BSC. Therefore, the objective of the paper is to examine the connection between corporate culture and the usage of BSC from the context of Iraq.

This paper examines corporate culture as a conditional variable that is expected to affect the frequency of treatment of performance measures for the following reasons. Firstly, few of the previous studies have investigated this factor. Secondly, this factor is important with respect to Iraqi companies in order to open the way for this study to be compared with other studies in other sectors and countries.

In perspective on the above mentioned, the rest some portion of this study is organized as pursues: The following part talks about the review of the literature and theoretical framework and development of suppositions. The area that pursues finishes up and creates future exploration suggestion.

\section{LITERATURE REVIEW}

\section{A. Balanced Scorecard (BSC)}

The BSC is a broad context that interprets the company's instruments [17]. Simons [18] looks at the BSC as that performance measure which interconnects the numerous associated goals that firms must accomplish to compete centered on their intangible resources and innovations. After more than 20 years since been introduced, BSC has continuously produced immense curiosity in academia and industrial arenas [19]-[20]. The BSC was developed to overcome the weakness of traditional fiscal measures, which are oriented to the short term, have a limited focus and are deemed insufficient for assessing total continuing company performance [1], [21]. The BSC is a holistic PMS tool as it contains both fiscal and non-fiscal measures organized usually into four viewpoints (financial, internal business, customer, and, learning and growth) to deliver top management with a quick and thorough picture of the company [1],[21]. Additionally, BSC gives benefits to organization to better understand its clienteles and markets, facilitates to concentrate on what is essential, and enhances worker enthusiasm and work satisfaction [22]-[23].

In general, it is acknowledged that organizations which execute formal PMS adjusted as far as financial and nonfinancial related pointers will remain in front of their rivals [24]. BSC demonstrates the balanced contemplations that are given to the long and short term fiscal and non-fiscal goals of the firms. In light of the organization of BSC, its suggestion is that organizations utilizing it must contemplate equally long haul and transient fiscal and non-fiscal. Various examinations in the area of management accounting and others have set up a connection between the BSC and company performance [25]-[26].

BSC encompasses four alternate points of view, including learning and growth; internal business process; customer; and financial perspective [1]. Learning and growth are viewed as the spine for the effective usage of BSC, as it causes workers to adopt new abilities and data frameworks [27]. The perspective emphasizes the ability to change and improve. This will be reflected in employees' abilities. strategic goals into a comprehensible set of performance

Information systems resources, employee motivation, empowerment and orientation [1]. The suggested measures such as a number of suggested improvements per employee, employee turnover, employee satisfaction, and hours of training for each employee. The internal business process perspective focuses to satisfy shareholders and customers [1]. It connects to the productivity and efficiency of organizational processes. The managers need to identify critical internal processes and develop a strategy to enhance customer satisfaction. Some examples of measures are the ratio of sales from innovative products, time to developing the next generation of product reworks, yields and returns. The customer perspective is related to customer satisfaction, which is in order to attain organizational vision, how should company seem to its clients [1]. In this viewpoint, the managers need to recognize the consumer and market segments that they want to enter. It captures the capability of a company to deliver quality products, efficiency of their distribution and whole customer assistance and satisfaction. Choosing measures from the customer perspective, a BSC, depend on the sort of clients and their wants in light of the worth that the association is giving to them [28]-[29]. The dimensions for this perspective can be products/services aspects, customer relations, and image and repute [7]. The financial perspective covers organizational financial goals [1]. This perspective uses historical traditional fiscal measures such as profit, ROI, and ROA. Various categories of measures are employed for each assessment - exterior, interior, result measures, performance drivers, objectives and particular measures that are related to one another via cause-and-effect links to the overall fiscal goals [21].

These four viewpoints are utilized as the all-inclusive performance measures assisting the organization to stay on course of action. Given the importance of BSC, there is a solemn requirement for broad research especially in the area of accounting but knowledge has shown that pragmatic assistance in this viewpoint is very limited thereby suggesting ongoing research [26].

The studies on BSC are limited in the Arab countries. Given the changing in Arab countries' business environment, there is a need for future research to investigate performance measurement practices such as BSC and other management accounting techniques and practices in Arab countries and to assess the impact of various contextual factors on their usage [30]-[31].

\section{A. Corporate Culture}

Corporate culture as defined by Branine [32] is the "consists of shared vision, systems, processes and procedures". These four aspects are shaped by the individuals on whom the organization relies on, from the ideas of the establishment members or managing directors of the company to the process being carried out by personnel at the shop-floor level" (p. 21-22). Likewise, Uttal [33] argued that corporate culture is a scheme of common values and principles, which has an interaction with employees; it shapes their behavior, structure of the 
organization, and control systems. Thus, it would be right to say that corporate culture represents a complicated whole that is full of principles, values, expectations, images, and characteristics that determine the behavioral styles of an organization - of which coordinates the level of interaction among various actors (the employees, consumers, suppliers, and competitors of the organizations) to affect the firm performance [34].

The most precise and compact description of corporate culture is given by Schein [35], who emphasized that culture of an organization is the circumstantial arrangement which is composed of a series of presumptions that are vital for the success of an organization. Such a circumstantial arrangement might be established or conceived by a specific unit in order to cope with a critical situation, created during the adaption phase. This framework is accomplished in the course of time, it is the total of a succession of creative perceptions, thinking, and attitude. This is thought to be valid for problem-solving when these characteristics are transferred to the new employees who join the organization at a later stage.

According to the literature on firm behaviour, corporate culture has four distinct characteristics. The first characteristic is the phenomenon of shared values [36]. The second attribute of corporate culture is that it has less visible levels [36]. The third attribute of corporate culture is that up-coming employees learn the prevailing culture [36]. The fourth and final attribute of corporate culture is that it changes very slowly [36]. The synthetic structure is that it is formed by the employees of an organization who usually share similar values like beliefs, and move collectively towards the achievement of a common goal [37].

Corporate culture is, therefore, a sustaining set of fundamental principles, beliefs, understandings, and methodologies that differentiate the organization and its representatives from others [38]. Generally, it is the argument of many researchers that success-oriented culture of an organization leads to effective firm performance [39]. According to this context, the influence of corporate culture over the performance of organizations has been analyzed with different variables in many studies [40]. Ultimately it was established that corporate culture leads to competitive advantage (e.g. Acar [37]).

On the other hand, Denison [41] argued that four traits of corporate culture could be identified, and these four traits have a major impact on firm performance. These four traits are 1) flexibility, 2) participation, 3) mission and 4) reliability. Adaptability refers to the capability to perceive the external environment; responding internally to customers, and the reaction to both internal and external customers. These require abilities like restructuring and reorganizing, and, without these abilities, an organization will find difficulty in gaining success [42]. The theory of involvement argues that a feeling of possession and accountability can be created in the employees by involving them in the decision-making procedure [39], [43]. In line with this theory, employees who have high involvement in the process of decision making and have autonomy usually perform better [44]. A mission statement provides the purpose for the survival of an organization via its social role. It also provides direction and clarity necessary for firm

performance. Organizations succeed when they are goal oriented [41], [44]. That is to say, the goals of organizations should be coordinated and aligned with the organizational structure and positive behaviors of employees [45]. A strong and positive culture that includes shared beliefs and values among the employees of an organization assists them in coordinating their functions [44]. The success of organizations is dependent on continuity. The basic concept implies an implied control system that is based on internalized values. Internalized values are effective means for the development of coordination between rules and regulations and external control systems [41]. Because the aim of the current research was to analyze the influence of corporate culture on the performance measurement system, the study focused on Denison's [41] cultural dimensions.

\section{B. Corporate Culture and Balanced Scorecard}

Literature has indicated proof that the achievement of BSC usage is connected with corporate culture. Without a doubt, Kaplan [46] (p. 56) saw that organizations with fruitful BSC usage "had a culture wherein individuals were profoundly mindful of and disguised the mission, vision, and basic beliefs expected to execute the organization's technique". In connection to this, having persuaded that information has turned into a reason for rivalry. As per this, BSC can be viewed as a pointer of the corporate culture. Thus, by considering BSC including money related and nonmonetary measures, we can get a few impressions about social typologies of associations, and how these measures are utilized by the executives. In this specific situation, it is conceivable to contend that BSC has a positive connection between control esteems culture and conventional PMS [47]. The fundamental driver of this is the hypothetical connection is that both of two spotlight on ideas, for example, control, dependability, chain of importance correspondence shapes in hierarchical administration.

In any case, nonfinancial execution estimates center around procedure and in this setting underline things like investigating constantly vital needs, real and twofold confronted input, adaptable and casual control [48].

Furthermore, the basic purpose of BSC is to transform organizations according to firm change, which is considered as the aim of the corporate culture. By implementing BSC the environment of business organizations has changed to the knowledge-based environment [49]. BSC has the capability to link cause and effect model with tangible and intangible assets [49]. This is the core cultural element that should be inculcated for value creation. At the same time, Brown [50] suggested that embedding the values in BSC is compulsory for success. The researcher has also perceived culture as such a distinct characteristic which cannot be replicated by any organization. Communication between leaders and followers also plays an important role in the successful implementation of BSC. If the communication is poor then the employees may be restrictive in adopting a new culture and will resist BSC. Employees resist BSC because they feel that the implementation of BSC is useless. 
Carmona [51] and Woodley [52] highlighted that corporate culture has a very important role while implementing BSC. The researchers also demonstrated that firm success is highly dependent on corporate culture.

The successful implementation of BSC is highly dependent on the culture where mission, vision, and objectives are translated into actions [46]. Researchers have also shown that the culture of the organization directly influences the implementation of BSC [53]-[54]. Based on the above explanation, the following hypothesis has been developed on the corporate culture and use of BSC.

\section{H1:}

There is a positive relationship between corporate culture and the use of BSC

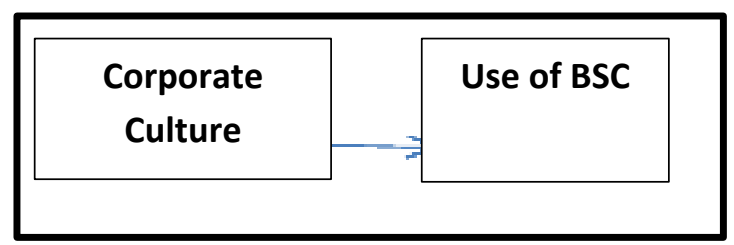

Fig.1.Research Framework

\section{METHODOLOGY}

This paper adopted a quantitative research design. Data were collected from 301 manufacturing companies in Iraq which represent $49.83 \%$ of the population. Smart PLS in this study was used to analyze the data. The two-steps analytical approach as suggested by Chin [55] was adopted to analyze the data: first, to the assessment of the measurement model for reliability and validity and second, the structural model [56]. To measurement the variables of this study we adopted most of the variables from the past studies. We have made some changed for some of the items to adapted and reflect the context of this study. We used an instrument developed by Kaplan [27] to measured BSC. The instruments have 20 items these items divided into four dimensions which are: financial, customer, internal business process, and learning and growth. Finally, corporate culture was measured using four dimensions from Denison [41].

\section{A. Profile of Respondents}

The first part of the questionnaire gathered information on the demographic characteristics of the respondents. This section describes the background of the respondents who participated in this study as illustrated in Table 1.

\section{RESULTS AND DISCUSSIONS}

This paper used the Partial Least Square Structural Equation Model (PLS-SEM) for the analysis taking advantage of Smart PLS 3.0 software [56].

First of all, algorism was run to determine the measurement model of the paper. Thereafter, the bootstrapping technique was run to determine the structural model as shown in the following subsections.

Table1. Profile of Respondents $(\mathbf{N}=301)$

\begin{tabular}{|c|c|c|c|}
\hline \multicolumn{2}{|c|}{ Item } & \multirow[t]{2}{*}{ Frequency } & \multirow{2}{*}{ Percentage $(\%)$} \\
\hline 1 & Gender & & \\
\hline & Male & 230 & $76.4 \%$ \\
\hline & Female & 71 & $23.6 \%$ \\
\hline \multirow[t]{5}{*}{2} & Position & & \\
\hline & $\begin{array}{ll}\text { Chief } & \text { Executive } \\
\text { Officers } & \end{array}$ & 89 & $29.6 \%$ \\
\hline & $\begin{array}{ll}\text { Chief } & \text { Financial } \\
\text { Officers } & \end{array}$ & 11 & $3.7 \%$ \\
\hline & $\begin{array}{l}\text { Chief Management } \\
\text { Accountants }\end{array}$ & 178 & $59.1 \%$ \\
\hline & Chief Controller & 23 & $7.6 \%$ \\
\hline \multirow[t]{11}{*}{3} & Industry & & \\
\hline & Food and beverage & 60 & $19.9 \%$ \\
\hline & $\begin{array}{l}\text { Textile and wearing } \\
\text { apparel }\end{array}$ & 65 & $21.6 \%$ \\
\hline & $\begin{array}{l}\text { Wood and wood } \\
\text { products }\end{array}$ & 34 & $11.3 \%$ \\
\hline & Electric and electronic & 17 & $5.6 \%$ \\
\hline & Non-metallic menial & 39 & $13 \%$ \\
\hline & $\begin{array}{l}\text { Paper and paper } \\
\text { product }\end{array}$ & 18 & $6 \%$ \\
\hline & Chemical products & 36 & $12 \%$ \\
\hline & Plastic product & 12 & $4 \%$ \\
\hline & Iron and steel & 13 & $4.3 \%$ \\
\hline & Machinery products & 7 & $2.3 \%$ \\
\hline
\end{tabular}

\section{A. Measurement model (Outer model)}

The measurement model was examined together with the convergent validity of the constructs. One item (CP6) was deleted due to low loadings. All other items of the construct have achieved the required loading above 0.7 , composite reliability above 0.7 and AVE above 0.5 [57]. See Figure 2 and Table 2. 


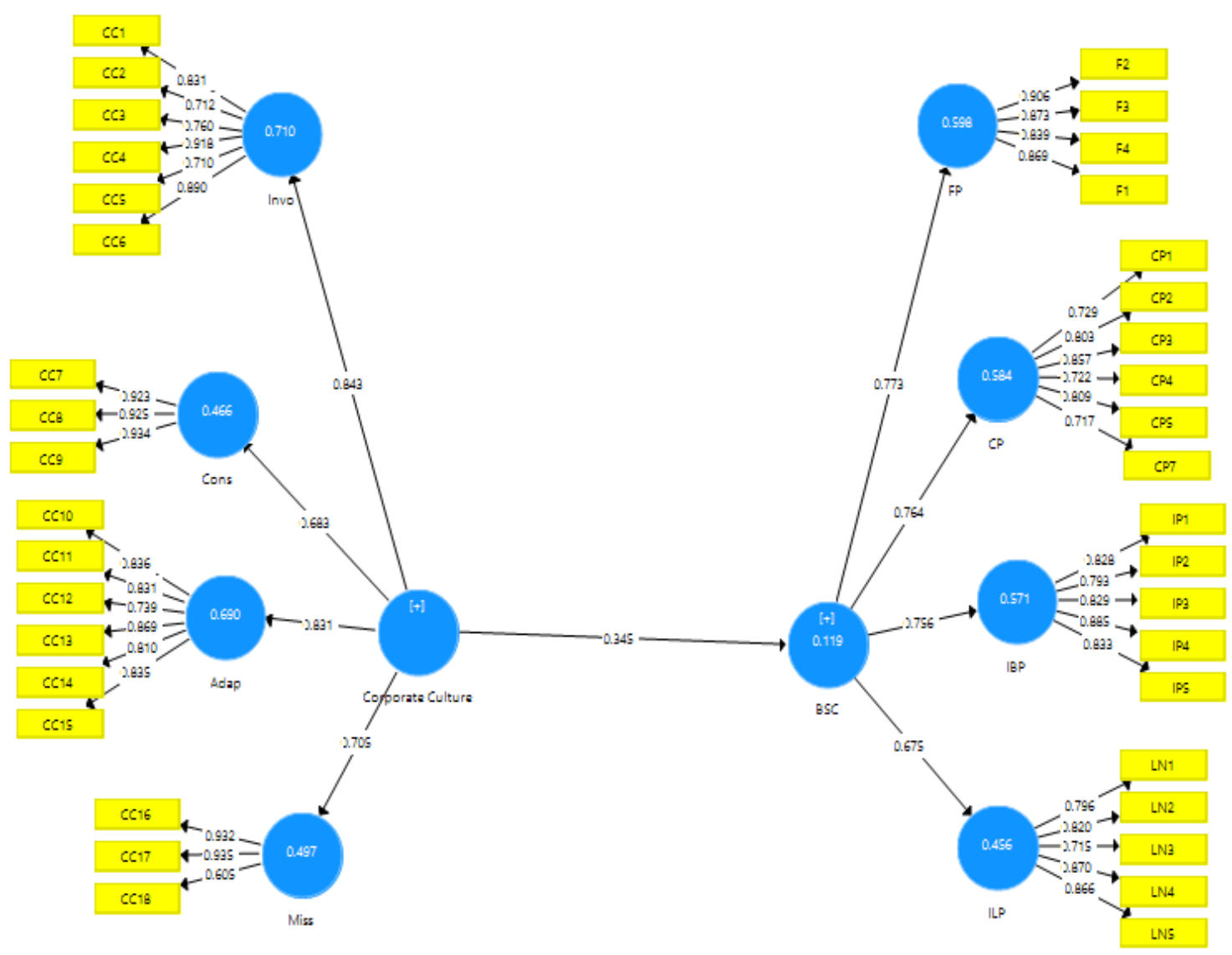

Fig.2. Measurement model

Table2. Reliability and Validity of Construct

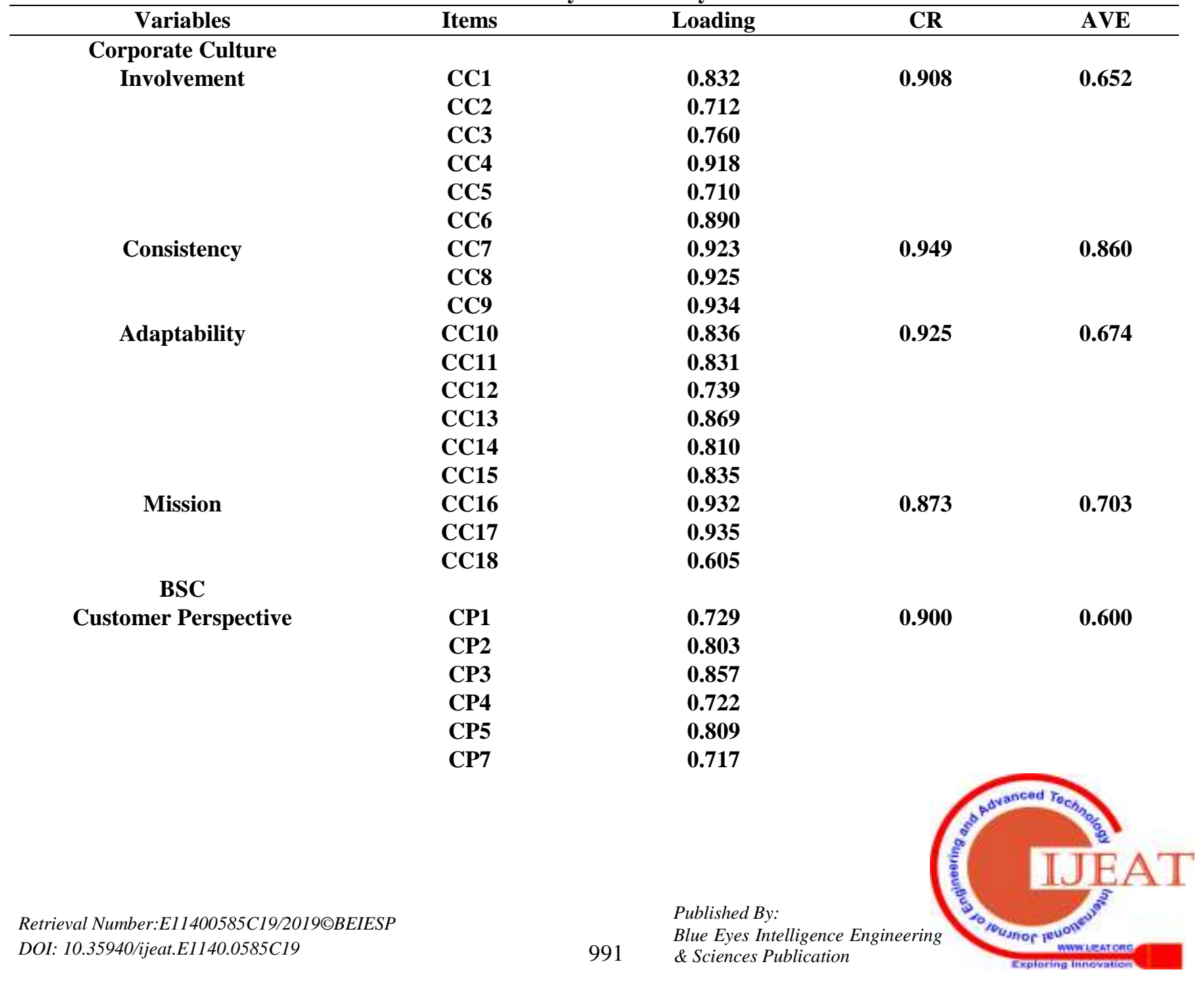


International Conference on Recents Advancements in Engineering and Technology (ICRAET-18) |15th and 16th March 2019|Siddhartha Institute of Technology \& Sciences, Telangana, India.

Financial Perspective

Internal Business Process

Fig. 3.Structural model

Table 3. Result of the Structural Model

\begin{tabular}{cccc}
\hline Relationship & Beta & T Statistics & P Values \\
\hline CC -> BSC & $\mathbf{0 . 3 4 5}$ & $\mathbf{6 . 9 0 1}$ & $\mathbf{0 . 0 0 0}$ \\
\hline
\end{tabular}

This study found that corporate culture significantly affects BSC usage in the Iraqi manufacturing companies, thus, the hypothesis is supported. The empirical finding is in line with previous studies that confirm a positive influence of corporate culture on firm performance [16],[58]. For example, Rababah [16] found that cultural factors like attention to detail and innovation have a significant relationship with BSC implementation.

Corporate culture has a deep impact on a variety of organizations processes and employees, which ultimately has a positive influence on firm performance and its measurement systems such as BSC [59].

This describes the influence of culture on the different process and parts of the firm, which contribute to the overall performance, in this regard, research shows that if employees are committed and have the same norms and

0.906
0.873
0.839
0.869

0.927

0.760

0.793

0.828

0.829

0.833

0.885
0.796
0.820
0.715
0.870
0.866

0.696

values as their organizations have, then performance directed at achieving overall organizations goals increases. Given the widespread interest in the potential effects of corporate culture on firm performance, there is evidence that corporate culture is positively associated with employee attitudes and performance (e.g, Bezrukova [60]). Accordingly, the managers of the Iraqi manufacturing companies should develop a strong corporate culture to encourage the use of a variety of performance measurements such as BSC.

\section{CONCLUSION}

The discussion of the study basically focused on the research objective which state that to examine the positive relationship between corporate culture and the use of BSC. The result revealed that corporate culture has an impact on the use of BSC. The hypotheses were supported with a beta value of 0.345 signifying a greater contribution of the corporate culture. Therefore, this study has confirmed that there is a positive relationship between corporate culture and the use of BSC in Iraqi manufacturing companies. In addition, this result is in line with the assumptions of contingency theory.

It has also presented suitable proof for the Iraqi manufacturing firms for creating strategic tactics in the use of BSC in determining and measuring their business success.

The paper has contributed to testing these instruments in an Iraqi context. Similarly, it has contributed to developing and testing research hypotheses.

The finding of this study would be of relevance to policymakers such as management of manufacturing companies and the Iraqi government.

This study proposes that if corporate culture and use of BSC are interdependent, they achieve vital goals in the organization. Interdependence in the context of our study means that the usefulness of one managerial concept depends on what other managerial concepts are in use, i.e. that the value of corporate culture depends on the use of BSC and vice versa. This means that if an organization does not take the interdependence among managerial concepts 
into account, it will forego some benefits or incur some unnecessary costs. The existence and importance of so defined managerial concepts interdependencies have been raised multiple times in the literature (see e.g. [61]-[64].

The current study contributed theoretically and practical as well, as follows. The contribution of this study is the extension of the contingency theory by adding empirical validation from medium- and large companies with respect to Iraq in the maximization of efficiency and effectiveness of designing performance measures through the relationship between corporate culture and BSC. For the first time from the context of Iraqi, literature has now emerged about the effect of corporate culture on BSC. The empirical evidence proves that corporate culture has a positive significant effect on BSC.

Despite its various contributions regarding the BSC in Iraqi manufacturing companies, as is always the case in doing research work, the current study has several limitations. First, the study focused primarily on medium and large industrial companies in Iraq and therefore may not be valid for small companies because of the poor documentation of financial and non-financial activities, which may hinder the use of BSC. Second, this study adopted a cross-sectional design, which was conducted at one point in time and did not show the BSC over time. Moreover, the study employed a primarily quantitative approach as the main research methodology.

In conclusion, this paper has introduced and examined the relationship between corporate culture and the use of BSC in Iraqi manufacturing firms. The paper concludes that there is an effect of for the corporate culture on the use of BSC. The paper recommends that future researchers are to extend the scope of the research for wider generalization. Also, the research frame should be tested in a service-oriented sector.

\section{REFERENCES}

1. R.S. Kaplan, and Norton, D. P, "The balanced scorecard measures that drive performance", Harvard Business Review, 70(1), 1992, pp.71-79.

2. M. Georgiev, "The role of the balanced scorecard as a tool of strategic management and control", Journal of Innovations \& Sustainability. 3(2), 2017, pp.31-63.

3. P.R. Niven, "Balanced scorecard step-by-step: Maximizing performance and maintaining results", New York: John Wiley \& Sons, 2006.

4. A.D. Neely, J. Mills, K. Platts, M. Gregory, and H. Richards, "Realizing strategy through measurement", International Journal of Operations \& Production Management, 14(3), 1994, pp.140-152.

5. Chow, and W. Van der Stede, "The use and usefulness of nonfinancial performance measures", Management Accounting Quarterly, 7(3), 2006, pp.1-8.

6. R.S. Kaplan, and D.P. Norton, "Transforming the balanced scorecard from performance measurement to strategic management: Part 1", Accounting Horizons, 15(1), 2001, pp.87-104.

7. M. Chavan, "The balanced scorecard: a new challenge", Journal of Management Development, 28(5), 2009, pp.393-406.

8. Z. Hoque, and W. James, "Linking balanced scorecard measures to size and market factors: Impact on organizational performance", Journal of Management Accounting Research, 12(1), 2000, pp.1-17.

9. J. Sandström, and J. Toivanen, J, "The problem of managing product development engineers: Can the balanced scorecard be an answer?", .International Journal of Production Economics, 78(1), 2002, pp.79-90.

10. G. Speckbacher, J. Bischof, and T. Pfeiffer, "A descriptive analysis of the implementation of balanced scorecards in German-speaking countries", Management Accounting Research, 14(4), 2003, pp.361-387.

11. D.R. Hansen, M. M. Mowen, D.W. Senkow, and R.M. Pollanen, "Strategic performance evaluation and management. In Management Accounting, $\left(6^{\text {th }}\right.$ Canadian ed.) Scarborough, Ontario: Nelson Thompson Learning, 2004.

12. J. Fisher, "Contingency theory, management control systems, and firm outcomes: Past results and future directions", Behavioral Research in Accounting, 10, 1998, pp.47-64

13. Sila, "Examining the effects of contextual factors on TQM and performance through the lens of organizational theories: An empirical study", Journal of Operations Management, 25(1), 2007, pp.83-109.

14. J. Deem, B. Barnes, H. Huizenga, S. Segal, and R. Preziosi, R, "The relationship of organizational culture to balanced scorecard effectiveness", SAM Advanced Management Journal, 75(4), 2010, pp.31-39.

15. J.F. Henri, "Organizational culture and performance measurement systems", Accounting, Organizations and Society, 31(1), 2006, pp.77-103.

16. Rababah, "The relationship between cultural factors and balanced scorecard implementation", International Review of Management and Business Research, 4(4), 2015, pp.1208-1218.

17. R. Kaplan, and D. Norton, "Putting the Balanced Scorecard to work", Harvard Business Review, September-Oct, 1993, pp.134.

18. R. Simons, R, "Performance measurement \& control systems for implementing the strategy: text \& cases", Prentice-Hall, Inc., Englewood Cliffs, New York, 2000.

19. F. Barnabe, and C. Busco, "The causal relationships between performance drivers and outcomes: reinforcing balanced scorecards' implementation through system dynamics models", Journal of Accounting \& Organizational Change, 8(4), 2012, pp.528-538.

20. Z. Hoque, "20 years of studies on the balanced scorecard: Trends, accomplishments, gaps, and opportunities for future research", The British Accounting Review, 46(1), 2014, pp.33-59.

21. Tennant, and M. Tanoren, "Performance management in SMEs: a Balanced Scorecard perspective", Int.J. Business Performance Management, 7(2), 2005, pp.123143.

22. M. Frigo, and K.R. Krumwiede, "The balanced scorecard: A winning performance measurement system", Strategic Finance, 81 (7), 2000, pp.50-54.

23. Martha S. Doran, Kamal Haddad, and Chee W. Chow, "Maximizing the success of balanced scorecard implementation in the hospitality industry", International Journal of Hospitality \& Tourism Administration, 3(3), 2002, pp.33-58. DOI: 10.1300/J149v03n03_05

24. N. Kartalis, J. Velentzas, and G. Broni, "Balance scorecard and performance measurement in a greek industry", Procedia Economics and Finance, 5, 2013, pp.413-422.

25. R. Guidara, and K. Walid, "Balanced scorecard and performance in a competitive environment", International Journal of Accounting and Economics Studies, 2(1), 2014, pp.40-45.

26. R. Jusoh, "Environmental uncertainty, performance, and the mediating role of balanced scorecard measures use: 
Evidence from Malaysia", International Review of Business Research Papers, 4(2), 2008, pp.116-135.

27. R.S. Kaplan, and D.P. Norton, "Linking the balanced scorecard to strategy", California Management Review, 39(1), 1996, pp.53-79.

28. P.R. Niven, "Balanced scorecard step-by-step: Maximizing performance and maintaining results", New York: John Wiley \& Sons, 2002.

29. Farooq, and Z. Hussain, "Balanced scorecard perspective on change and performance: A study of selected Indian companies", Procedia-Social and Behavioural Sciences, 24, 2011, pp.754-768.

30. H.A. Al-Khadash, and M. Feridun, M, "Impact of strategic initiatives in management accounting on corporate financial performance: Evidence from Amman Stock Exchange", Managing Global Transitions, 4(4), 2006, pp.299-312.

31. R. Shurafa, and R. Mohamed, "National culture and management control systems using levers of control framework: An empirical analysis", Journal of Islamic, Social, Economics, and Development, 3(10), 2018, pp.37-53.

32. M. Branine, "Managing Across Culture - concepts, policies, and practices", Thousand Oaks, California: SAGE Publication Inc, 2011.

33. Uttal, B, "The corporate culture vulture", Fortune, 108(8), 1983, pp.66.

34. J.B. Barney, "Organizational culture: Can it be a source of sustained competitive advantage?", Academy of Management Review, 11, 1986, pp.656-665.

35. E.H. Schein, "Organizational culture and leadership", San Francisco: Jossey-Bass, 1985.

36. R.J. Baumgartner, "Organizational culture and sustainable corporation", Sustainable Development, 17, 2009, pp.102-113.

37. A.Z. Acar, and P. Acar, "Organizational culture types and their effects on organizational performance in Turkish hospitals", Emerging Markets Journal, 3(3), 2014, pp.18-31.

38. K. Cameron, and R.E. Quinn, "Diagnosing and changing the organizational culture: Based on the competing values framework", Readings, MA: Addison-Wesley, 1999.

39. D.R. Denison, (1990). "Corporate culture and organizational effectiveness", New York: John Wiley \& Sons, 1990.

40. Ogbonna, and L. Harris, L, "Leadership style, organizational culture, and performance: Empirical evidence from UK companies", International Journal of Human Resource Management, 11(4), 2000, pp.766-788.

41. D.R. Denison, "Organizational culture (OC): Can it be a key lever for driving organizational change. In $\mathrm{S}$. Cartwright \& C. Cooper (Eds.), The handbook of organizational culture $(O C)$ and climate. Chichester, England: Wiley, 2000. pp.347-376.

42. E.H. Schein, "Organizational culture", American Psychologist, 45(2), 1990, pp.109-119.

43. N.H. Abdullah, A. Shamsuddin, E. Wahab, and N.A.A. Hamid, "The relationship between organizational culture and product innovativeness", Procedia- Social and Behavioral Sciences, 129, 2014, pp.140-147.

44. D.R. Denison, L. Nieminen, and L. Kotrba, "Diagnosing organizational cultures: A conceptual and empirical review of culture effectiveness surveys", European Journal of Work and Organizational Psychology, 23(1), 2014, pp.145-161.

45. A.K. Al-Swidi, and R. Mahmood, "Total quality management, entrepreneurial orientation and organizational performance: The role of organizational leadership: Preconditions for the development of a

culture", African Journal of Business Management, 6(13), 2012, pp.4717.

46. R.S Kaplan, and D.P. Norton, "Measuring the strategic readiness of intangible assets", Harvard business review, 82(2), 2004, pp.52-63.

47. M.A. Abernethy, and A.M. Lillis, "The impact of manufacturing flexibility on management control system design", Accounting, Organizations and Society, 20(4), 1995, pp.241-258.

48. L. Gordon, and V. Narayanan, "Management accounting system perceived environmental uncertainty and organization structure: An empirical investigation", Accounting, Organizations and Society, 9(1), 1984, pp.33-47.

49. R.S. Kaplan, and D.P. Norton, "The strategy focused the organization on how balanced scorecard companies thrive in the new business environment", Boston, MA: Harvard Business School Press, 2001.

50. M.G. Brown, "Winning score: How to design and implement organizational scorecards", New York: Productivity Press, 2000.

51. S. Carmona, G. Iyer, and P.M. Reckers, "The impact of strategic communications, incentives and national culture on balanced scorecard implementation", Advances in Accounting, 27(1), 2011, pp.62-74.

52. P.M. Woodley, "Culture management through the balanced scorecard: A case study", Ph.D. Dissertation, Cranfield University, Unpublished, 2006.

53. U.S. Bititci, K. Mendibil, S. Nudurupati, T. Turner, and P. Garengo, "The interplay between performance measurement, organizational culture and management styles", Measuring Business Excellence, 8(3), 2004, pp.28-41.

54. Assiri, M. Zairi, and R. Eid, "How to profit from the balanced scorecard: An implementation roadmap". Industrial Management \& Data, 106(1), 2006, pp.937952.

55. W.W. Chin, "How to write up and report PLS analyses", Handbook of partial least squares, 2010, pp.655-690.

56. Ringle, S. Wende, and A. Will, Smart-PLS Version 2.0 M3. The University of Hamburg, 2005. http://www.smartpls.com.

57. J.F. Hair, M. Starstedt, L. Hopkins, and G. V. Kuppelwieser, "Partial least squares structural equation modeling (PLS-SEM)". London, England: SAGE Publications, 2014

58. Y. Berson, S. Oreg, and T. Dvir, T, "CEO values, organizational culture, and firm outcomes", Journal of Organizational Behaviour, 29(5), 2008, pp.615-633.

59. Shahzad, R.A. Luqman, A.R. Khan, and L. Shabbir, "Impact of organizational culture on organizational performance: An overview", Interdisciplinary Journal of Contemporary Research in Business, 3(9), 2012, pp.975985.

60. K. Bezrukova, S. Thatcher, K.A. Jehn, and C.S. Spell, "The effects of alignments: Examining group faults lines, organizational cultures, and performance", Journal of Applied Psychology, 97(1), 2012, pp.77-92.

61. R.H. Chenhall, "Management control systems design within its organizational context: findings from contingency-based research and directions for the future", Accounting, Organizations and Society, 28(2), 2003, pp.127-168.

62. Furlan, A. Vinelli, and G. Dal Pont, G, "Complementarity and lean manufacturing bundles: an empirical analysis", International Journal of Operations \& Production Management, 31(8), 2011, pp.835-850. 
Doi:10.1108/01443571111153067

63. Grabner, and F. Moers, "Managers' choices of performance measures in promotion decisions: An analysis of alternative job assignments", Journal of Accounting Research, 51(5), 2013, pp.1187-1220.

64. M. Aoun, and N. Hasnan, "Lean production and TQM: complementary or contradictory driving forces of innovation performance?", International Journal of Innovation Science, 5(4), 2013, pp.237-252.

\section{AUTHORS PROFILE}

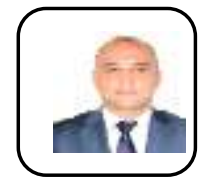

received

Khalis Al-Naser received his B.Sc. in Accounting in 2001 from University of Mosul, Iraq. Then, he received his M.Sc. degree in Cost Accounting in 2005 from the University of Mosul, Iraq. He is working as a lecturer at Accounting Department, Administration and Economic College, University of Mosul, Iraq. After that, he his Doctor of Philosophy (Ph.D.) in (Cost and Management Accounting) from Universiti Utara Malaysia (UUM), Malaysia in 2018, He led or member for many funded research projects and he has published more than 15 papers at various international journals. His research areas are Cost and Management Accounting. Currently, he is working as a lecturer at the Department of Accounting, Administration and Economic College, University of Mosul, Iraq. Email:Alnaser7171@yahoo.com

Rapiah Mohamed is an Associate Professor at the

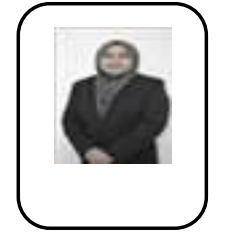

Tunku Puteri Intan Safinaz School of Accountancy, Universiti Utara Malaysia. Her Ph.D. in Accounting was awarded by Universiti Teknologi MARA (UiTM), Shah Alam, Malaysia in 2011. She is also a member of the Institute of Certified Management Accountants, Australia (CMA) since 2011. Her research interests include a management control system, performance measurement, and environmental management accounting. Currently, she is involved in research projects related to management accounting and environmental management accounting. Email: rapiah@uum.edu.m 